УАK 331.108

ББК 60.823 .3

DOI 10.22394/1682-2358-2018-4-23-29

I.N. Osipova, Candidate of Sciences (History), Docent of the Public Administration Department, Povolzhsky Institute of Management named after P.A. Stolypin, Branch of the Russian Presidential Academy of National Economy and Public Administration

\section{CRITERIA \\ FOR ASSESSING \\ THE SOCIAL \\ PERFORMANCE OF EMPLOYEES}

The results of the implementation of state social programs and projects in the Russian Federation are analyzed. The author highlights the need to form indicators for assessing the social efficiency of employees. Proposals aimed at the development of the system of personnel assessment in the public service are formulated.

Key words and word-combinations: social effect, personnel evaluation system, employee, evaluation criterion.
И.H. Осипоßа, кандидат исторических наук, дочент кафедри государственного и муниципального упраһления Поволжского института управления имени П.А. Стольпина - филиала Российской академии народного хозяйства и государственной службь при Президенте РФ (етаі): OsipovaIrina1@yandex.ru)

\section{КРИТЕРИИ ОЦЕНКИ СОЩИААЬНОЙ ЭФФЕКТИВНОСТИ АЕЯТЕАЬНОСТИ САУЖКАЩИХ}

Аннотация. Анализируются результаты реализации в Российской Федерации государственных социальных программ и проектов. Обращается внимание на необходимость формирования показателей оценки социальной эффективности деятельности служащих. Сформулированы предложения, направленные на развитие системы оценки персонала на государственной службе.

Ключевые слова и словосочетания: социальный эффект, система оценки персонала, служащий, критерии оценки.

И деология менеджмента в оџенках эффективности Аеятельности служащих стала популярной в последние Аесятияетия реформаторских инициатив. Несколько раз происходила «переоценка ценностей» формирования системы оџенки персонала органов государственной и муниципальной власти, принципов и сущности функщионирования государственного аппарата [1, с. 90]. Идея разработки показателей эффективности Аеятельности служащих явцяется в настоящее 
время предметом целого ряда научных исследований и находится в центре Аискуссии о перспективах развития государственной и муниципальной службы как профессиональной деятельности.

Анализ научной китературы демонстрирует, что исследования данного вопроса могут быть объединены в Ава основных направления. В рамках первого направления ученые занимаются разработкой показателей результативности Аеятельности служащих, отражающих результат работы органа власти (конечный результат) и показателей, характеризующих качество принятия и исполнения управленческих и иных решений (непосредственный результат) [2, с. 15]. Второе направцение представцено изучением показателей оценки профессиональной компетентности служащих [3, с. 102].

В органах государственной власти наиболее распространенным является подход (методические рекомендации Минтруда РФ), при котором используются интегральные показатели результативности, ориентированные на техномогическую и экономическую эффективность, оџенку профессионацьной компетентности служащих [4, с. 153]. МежАу тем искцючительно экономический или технологический подход нивелирует общественную сущность госуАарственного управцения, смысл создания и функционирования органов вцасти, эффективность их соџиального проявления.

Безусловно, при оџенке, ориентированной на исслеАование социальной эффективности деятельности, возникнет сложность с определением конкретного вкцада отдельно взятого Аолжностного мица в решение той или иной проблемы. Тем не менее дальнейшее совершенствование системы оценки персонала в органах власти требует формулировки показателей, которые могут максимацьно отразить степень вкцада конкретного служащего. Анализ соџиального эффекта деятельности органов власти демонстрирует, что это является не только возможным, но и необходимым.

Формирование критериев оџенки социальной эффективности деятельности служащих Аолжно основываться на конкретных результатах и соџиальном эффекте от реацизации государственных программ как главного инструмента государственной политики. Приоритеты Российского государства в решении соџиальных вопросов наглядно прослеживаются в реализуемых в настоящее время государственных программах: «России важкен кажкдый ребенок», «Инклюзивное образование», «Аоступная среда», «Соџиальная поддержка граждан» и Аругих - своего рода основном критерии оџенки соџиальной эффективности Аеятельности органов власти в различных сферах жизнедеятельности. Оџенка итогов реализации государственных программ позволяет судить, в свою очередь, о

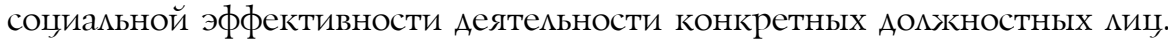

На примере результатов реализаџии государственной программы «Аоступная среда» продемонстрируем возможность социального подхода к оџенке эффективности деятельности служащих. Основным результатом реализации программы явцяется совершенствование правового регулирования форм соџиальной подАержки, а также порядка их предоставления. К сожалению, Аанные достижения не привели к качественным преобразованиям в социальной сфере. Современная соџиальная политика в России, основанная на медицинс-

24 Bulletin of the Volga Region Institute of Administration • 2018. Vol. 18. № 4 
кой модели, не позволяет в полной мере создать условия Аля реализаџии своих прав тем категориям граждан, которым требуется государственная поддержка. Сложившаяся практика функционирования органов власти не ориентирована на оценку соџиального эффекта, отражающего потребности и интересы гражАан, не воспроизводит устойчивые связи с институтами гражданского общества, не является источником Аальнейшего развития соџиальных иниџиатив.

Математические подходы к оџенке эффективности деятельности органов власти привели к созданию патерналистской модели соџиальной помощи, которая преАполагает мечение, пенсионное обеспечение, трудоустройство, $ь$ ьоты в сфере ЖККХ, но помогает человеку не жить, а выживать. Подобный подход не только ослабляет соџиальную позиџию государства, «высвечивая» неравенство и погрешности распределения соџиальных благ, но и обесценивает Аостижения государственной политики в этой сфере, создавая почву Аля возникновения соџиальных конфииктов и конфронтации. Казалось бы, государственная политика реализуется, показатели выполняются, но не достигается тот социальный эффект, который заключается прежде всего в степени

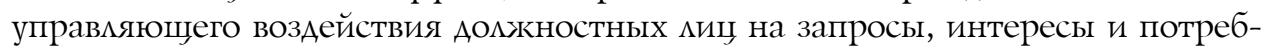
ности общества, решение соџиальных проблем граждан.

КАючевым элементом оџенки соџиальной эффективности деятельности служащих является механизм контроця. В настоящее время в соответствии с положениями нормативных правовых актов, утверждающих государственные программы, контроль наА реализацией мероприятий возцожен на государственный орган в конкретной сфере. Так, ответственным исполнителем госуАарственной программы «Аоступная среда» на 2011-2025 гг. является Министерство труда и социальной защиты РФ. В рамках обеспечения контроля наА реализацией мероприятий Аанной государственной программы приказом Минтруда России от 13 сентября 2012 г. № 184 создан координаџионный совет [5]. Анализ функций координационного совета Минтруда РФ, утвержАенных регламентом, Аемонстрирует их различные направления Аеятельности (утвержкдение плана работы, межведомственную координацию деятельности, рассмотрение тематики мероприятий и Ар.), но не включает осуществление контроля наА реализацией мероприятий государственной программы «Аоступная среда». В настоящее время Аействующим законодательством порядок контроля, процедуры его проведения не регламентируются.

Согласно отчетам ведомства доступная среда создается, но достоверность статистических данных, подтверждающих успешность реализаџии госпрограммы в полном объеме, вызывает сомнения. Системные проверки, характеризующие социальный эффект реализации госпрограммы, Минтрудом РФ не проводятся. Отсутствуют инструменты контроля и наА целевым характером использования различного рода субсидий. Министерством и органами исполнительной власти не ведется, например, мониторинг сохранения рабочего места за инвацидом или занятости (закрепцяемости) инвацида на созданном рабочем месте. Контроль осуществляется только посредством сбора и учета отчетов. В связи с этим оџенить эффективность расходов на проведение данного мероприятия вряА $\Lambda и$ возможно. 
Соџиальная эффективность деятельности служащих отражает соџиально значимые цеми и задачи органа вмасти и может быть оџенена посредством таких критериев, как законность, целесообразность и адекватность принятых управленческих решений. Итоги реализации государственных программ демонстрируют просчеты правового, финансово-экономического и организационного характера, отражая низкую социальную эффективность деятельности конкретных домжностных миџ. На федеральном уровне отсутствуют нормативные правовые акты, содержащие перечни направлений использования средств, выдеменных в рамках госпрограмм, что формирует риски финансирования мероприятий и осуществления расходов, не связанных с достижением стратегических целей государственных программ, а главное с достижением социального эффекта.

Анализ нормативных правовых актов, регулирующих вопросы обеспечения инвалидов техническими средствами реализаџии, показал, что они нуждаются в совершенствовании. Так, при замене кресел-колясок не предусматривается учет изменений антропометрических данных инвалида, состояния здоровья, степени соџиальной активности, работоспособности, возраста. Проџедурно не определена возможность отказа инвалида от предоставленного ему изделия.

В рамках реализации государственной политики на соџиальную сферу тратятся огромные бюджетные средства. Но то, что происходит, нельзя назвать эффективным управлением не только с точки зрения решения соџиальных вопросов, но и с позиџии эффективного и раџионального использования средств федерального и региональных бюАжетов.

Обращает на себя внимание тот факт, что отчеты о реализации программы и цифры офиџиальной статистики, результаты мониторинговых исследований, проводимые органами исполнительной власти, кардинально отличаются от независимых исследований, а также от результатов контрольных мероприятий, которые осуществляет Счетная палата РФ. Ее аудиторы заявцяют: «В отчетах о выполнении мероприятий Минтруд ежегодно указывал недостоверные сведения о количестве созданных рабочих мест дия инвалидов» [6] .

Анализ результатов аудиторских поверок, проведенных Счетной палатой РФ, обнаруживает целый ряА проблем неэффективного использования бюАжетных средств. Так, по итогам реализации госпрограммы в 2011-2015 гг., несмотря на увеличение финансирования госпрограммы «Аоступная среда» более чем в три раза, качество жизни мюдей с ограниченными возможностями здоровья заметно не улучшилось. Результаты контрольного мероприятия «Проверка целевого и эффективного использования средств федерального бюджета, выделенных в 2011-2015 годах на реализаџию государственной программы Российской Федерации «Аоступная среда» на 2011-2020 годы», продемонстрировали, что к сушественному повышению качества жизни инвамидов реализация госпрограммы пока не привема [7]. Выявлен ряд проблем, влияющих как на эффективность обеспечения инвалидов колясками, так и на рациональность и экономность расходования бюджетных средств.

Отсутствие контроля наА Аеятельностью уполномоченных органов в части организаџии конкурентных процедур привело к значительной дифференциа- 
ции их стоимости и неэкономному расходованию бюджетных средств. Средняя стоимость колясок в регионах, реализующих полномочия по обеспечению инвацидов ТСР, выше, чем в территориальных органах ФСС от 8 до 48\% [8] .

Неэффективно организованная система закупок приводит к дополнительному расходованию бюджетных среАств. Большое количество эпизодов, выявменных Счетной палатой РФ, свидетельствуют о приобретении технических средств реабилитации по ценам выше рыночных. В ряде случаев технические требования к креслам-коляскам, например в регионах, принимаются при значительном расширении потребительских свойств закупаемых кресел-колясок, что ведет к увеличению их стоимости.

Более $40 \%$ респондентов, принявших участие в проведенном Счетной паматой РФ опросе, отмечают, что оборудование соџиацьных объектов устройствами, обеспечивающими к ним беспрепятственный доступ инвацидов, проводится с нарушением требований и нормативов, еще $33 \%$ считают, что они

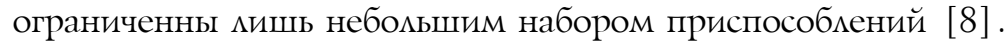

Социальный эффект детерминирован действиями конкретных Аолжностных миџ, оказывающих реальное управляющее воздействие на управцяемые объекты. Решение конкретных проблем граждан явцяется показателем социального эффекта. МежАу тем сложившаяся практика демонстрирует, что организация деятельности разАичного рода учреждений, фондов и иных учрежкдений, отвечающих за предоставление мер государственной поддержки, создает немало препятствий дия реализаџии гражданами своих прав на помучение мер государственной социальной поддержки. Ориентация на экономический подход в оџенке эффективности деятельности служащих приводит искиючительно к количественным показатемям реацизации государственных

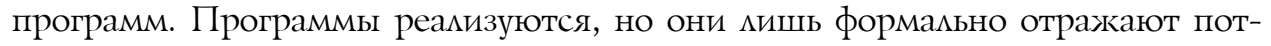
ребности соџиально незащищенных слоев и в большинстве случаев не решают проблем, с которыми сталкиваются инвациды, дети-инвациды и их родители, дети-сироты и Аети, оставшиеся без попечения, опекуны.

Статистические данные, а также мониторинговые исследования реализации государственной программы «Аоступная среда» свидетельствуют о неэффективности мер, направленных на обеспечение Аоступности соџиацьной инфраструктуры дия маломобильных граждан. Ааже там, где, казалось бы, здания и транспорт обеспечены необходимыми дия инвалидов техническими средствами, они мибо неудобны Аля использования, мибо неисправны. Формальное наличие транспорта, приспособленного дия нужА инвацидов, не в полной мере решает проблемы доступности среды Аля них.

Реальные примеры позволяют Аать низкую оџенку соџиальной эффективности конкретных должностных $\Lambda$ О. Отсутствует Аолжный контроль наА качеством составления индивидуальных программ реабилитации или абилитации инвалидов в части рекомендаций технических средств реабилитации. ИПР разрабатываются как «под копирку» и не содержкат достаточных характеристик рекомендуемых средств реабилитации, не учитывающих в полной мере индивидуамьных особенностей инвалидов, что предусмотрено приказом Минтруда России № 998н. Отсутствие индивидуаиьных характеристик в ИПР часто 
приводит к отказам от среАств реабилитации. Избыточные же технические и потребительские характеристики ТСР, указанные в ИПР, веАут к увеличению их стоимости. В подавцяюшем большинстве случаев средства реабилитаџии предоставцяются с нарушением сроков.

Положениями приказа Минтруда России № 998н при назначении ТСР не преАусмотрен учет условий жкизни инвалида. При принятии решения госуАарственным учреждением медико-социальной экспертизы об обеспечении креслами-комясками не учитываются жилищные условия (этажность, наличие в подъезде мифта, пандуса, размеры проемов и другое), индивидуальные потребности инвалидов, обусловленные характером заболевания.

По обозначенным проблемам бьют тревогу общественные организации. Как отмечает председатель совета Московской городской ассоџиаџии родитецей детей-инвалидов и инвацидов с детства (МГАРАИ) Ю. Камац, результаты нескольких опросов, проведенных среди самих инвалидов и семей, воспитывающих инвалидов, плачевные. В учреждениях санаторно-курортного типа и магерях госпрограмма практически не реализуется. «Обустроенных площадок крайне мало, практически нет, а те, которые есть, не используются по назначению. Аюди не могут поехать в предложенные санатории, потому что они недоступны дия маломобильных граждан. Положение серьезное, не были намечены конкретные мероприятия и цели по использованию огромных средств, а на саму «Аоступную среду» использовано очень мало» [9, с. 3] .

Отсутствуют единые требования к паспортам доступности, персонал не обучается навыкам работы с маломобильными инвацидами, а также с мюдьми с проблемами зрения, слуха, ментальной инвацидностью. "Аоступная среда» предполагает доступность не только в органы государственной и муниџипацьной вмасти, но и учреждений мюбой формы собственности, но механизм взаимодействия власти с ними пока не регламентирован.

Множкество подобных фактов делают очевидными критерии оџенки социальной эффективности деятельности служащих на разных уровнях управления.

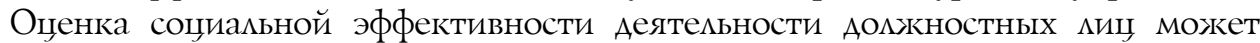
проводиться по двум видам критериев: общим и специфическим. К общим критериям относятся критерии, отражающие общую могику и приоритеты Аеятельности органа вмасти, его целей и задач - законность, целесообразность и адекватность принятых управленческих решений. Специфические критерии ориентированы на конкретные должностные обязанности служащего. Необходимым представмяется разработка и внедрение в систему оџенки персонала органов вцасти соответствующего инструментария (периодичности, формы, методов и субъектов оценки).

Безусловно, приведенные критерии не исчерпывают всех возможностей социального подхода к оџенке эффективности деятельности служащих. Аальнейшее развитие методологии оџенки эффективности деятельности служащих, совершенствование методик Аолжно проводиться с учетом основных целей реализации социальной политики в России, направленной на создание условий Аля Аостойной жизни, удовцетворение духовных и материальных потребностей гражАан. Критерии и показатели социального эффекта Аолжны разра- 
батываться с опорой на главные задачи социальной политики - обеспечение каждого гражданина доступным комплексом соџиальных благ, удовлетворяющих его необходимые биологические, материальные, соџиальные и духовные потребности.

\section{Библиографический список}

1. Осипова И.Н. Проблемы реформирования государственной службы: в поисках прагматических ответов // Вестник Московского университета. Сер. 21: Управление (государство и общество). 2011. № 1.

2. Дмитриева О.А. Проблемы и пути разрешения проблем оценки результативности деятельности таможенных органов // Таможенное дело. 2017. № 1.

3. Колесников А.В., Макаров А.О., Беляев М.А., Осипова И.Н. Комментарий к Федеральному закону от 2 марта 2007 г. № 25-Ф3. 2-е изд., перераб. и доп. Саратов, 2012.

4. Хатькова Е.А. Осипова И.Н. Методологические проблемы оценки эффективности деятельности государственных служащих // Региональная власть, местное самоуправление и гражданское общество: механизмы взаимодействия: сборник научных трудов. Саратов, 2018.

5. О Координационном совете по контролю за реализацией государственной программы Российской Федерации «Доступная среда» на 2011-2020 годы: приказ Минтруда России от 13 сент. 2012 г. № 184 (в ред. от 27 марта 2017 г.) (опубликован не был) [Электронный ресурс]. Доступ из СПС «КонсультантПлюс».

6. Годовой отчет Счетной палаты РФ в 2017 г. URL: https://specialitet.ru/lekcyi/godovoj_ otchet_schetnoj_palaty_2017.pdf.

7. Бюллетень Счетной палаты РФ. 2017. № 8, авг. URL: www.ach.gov.ru

8. Счетная палата: «Доступная среда» пока не улучшила жизнь инвалидов. URL: https:// www.miloserdie.ru/news/schetnaya-palata-dostupnaya-sreda-ne-uluchshila-zhizn-invalidov/

9. Конобеевская $H$. Счетная палата: «Доступная среда» пока не улучшила жизнь инвалидов» // Известия. 2017. 22 мая. 